The patient became worse ; incontinence increased. On February 14th, therefore, I gave two minims of carbolic acid thrice a day in water. "In four days, the urine was quite clear for the first time daring the last three months. The incontinence ceased; but, the urine being smoky, and pains in the stomach occurring, I stopped the carbolic acid, and gave quinine and irop.

March 4th. The urine was again milky.

March 14th. There was an inflammatory redness and swelling in the right parotid region; no fluctuation. Antisentically, I procured about twenty minims of blood from the inflamed part, and inoculated six tubes. The fresh blood contained micrococci. In two days, the tubes were teeming with active micrococci ; there were no bacilli nor bacteria. A few days later, the abscess, evidently pyæmic, burst into the external anditory meatus. It was treated antiseptically from the beginning, and remained sweet. A gauze dressing was applied before it burst. The pus showed micrococci from the commencement to the end, but no bacilli or bacteria were present.

The patient died on March 25th, and I made a post mortem examination seven hours after death. The bladder was congested and hypertrophied ; it contained about two ounces of milky urine. The prostate was enlarged; it contained two abscess-cavities, which commumicated with the rectum, but not with the bladder. The right kidney weighed $9 \frac{1}{2}$ ounces ; it was enlarged, and covered with much fat. On section, it was pale; and the cortex was not defined from the medulla. There were a few yellow spots, like minute abscesses. The pelvis of the kidney and the ureter were congested, and contained a few drops of milky urine. The left kidney weighed $7 \frac{1}{2}$ ounces. The calyces were much dilated, and contained a small abscess or cheesy matter of the sizc of a pin's head, as in the right kidney. The ureter was dilated. Milky urine was found in the dilated kidney.

Such are the facts of this curious case. I withheld the publishing of them four years ago, on account of its novelty.

REMARKs. - Years ago, Sir Joseph Lister insisted on the theory, or principle, that healthy tissues are capable of resisting organisms. As an instarice, one sees how the healthy urethra resists the passage of organisms, so abundant at its orifice, into the bladder. Conversely, whealthy or weakened tissues yield their substance as a soil for germs. What the power of resistance is, has not yet been fully explained.

The secret of all germ-diseases, however, rests on this grand principle. It explains this particular case. The patient, while in good health, had a wound on the genital organs, and a catheter was kept in the bladder for two or three days. What a grand opportunity for aërial germs to enter the bladder. If he had been an old man, or weak, he wouid have had "catheter-fever," so-called ; but, being strong and in health, he resisted the organisms, and they found no favourable soil in his body. Undoubtedly, the spores of this bacillus had been lodging in the urinary organs for years. When he was starved and his health failed, then the spores developed in his weakened body.

This is not all imagination, for we see it in every-day life. Take a person with decayed teeth, the canals in the fangs diseased, permitting organisms to pass up to the roots. Whilst in good health, they cause no trouble; bnt, if such an individual go out in a bitter wind, or become chilled, the result may be toothache and gumboil. Thus, only a temporary lowering of the vitality and circulation of the jaws was sufficient to permit the active development of organisms which, during health, were dormant.

In this case, the mischief occurred in the kidney, which presented no special lesion. The spores only existed in the urine. It is worth while noting that the early stage of the bacillus was a clear rod, filled with very finely granular matter. As development progressed, jointed rods, with a spore at each end, appeared.

My experiments show that the bacillus is a feebler organism than the bacterium, and that an active growth of the latter. prevented a development of bacilli. Quinine checked the bacillus, as in ague. Carbolic acid did so more effectually. I was struck with the fact that the prostatic abscess did not contaminate the bladder, though, through it, the patient fell a victim to pyæmia.

During the pyæmic state, the blood and the abscess contained micrococci, and no bacteria. The inoculations yielded only micrococci, and no bacteria. These experiments were carried out most accurately, with antiseptic jrecautions.

I have had little or no experience of pyæmia, having been a disciple of the illustrious Iister since my first days at Edipburgh. Undoubtedly, there are micrococci and micrococci ; for some observers allege that they have found them on antiseptic dressings, and declare them to be innocuous:

$\mathrm{I}$ would quote another case in which I discovered bacilli. In the spring of 1879 , I was asked to assist in tapping a young gentle- man, suffering from ascites. He had travelled in South America for four or five years, and came home a wreck. The cause of the ascites was unknown. He had no ague, no jaundice, no spleen-cake. I assisted at the fifth tapping, each time done antiseptically. This time thirty-three pints of ffuid were removed. As I wanted some pure serum for some experiments, I now saw my opportunity. I collected some in a glass-stoppered quart bottle. The bottle and stopper were soaked in carbolic acid solution ( 1 in 20 ) for twenty-four hours. After the spray was turned on, the lotion was poured out, the bottle filled with clear ascitic fluid, rinsed, emptied, and refilled. All was done under the spray. A wet carbolic rag was put outside the stopper, and carbolic gauze outside that.

The bottle was kept in a cool place for some days. To my surprise, it gradually became flaky and turbid. Under the spray, I opened the bottle, and examined its contents microscopically. I found the flakes and turbid material composed of large active bacilli ; some clear, some with spores and jointed; also micrococci. The original fluid was perfectly clear.

\section{NO'TES OF A CASE OF HEPATIC ABSCESS.}

\section{BY JOHN COCHRANE, L.R.C.P. and L.R.C.S.Ed.} Medical Officer for the Parish of Assynt, Lochinver.

THE rarity of the occurrence of single large abscess of the liver in this country is so well known, that I am desirous of narrating a case which lately came under my observation.

The patient was a middle-aged man, who had never been abroad, but had resided in Scotland for the greater term of his life. For several years past, he had suffered more or less from symptoms referable more particularly to some derangement of the digestive organs; in fact, such as might be termed "biliousness." Last year, he had a serious attack of severe vomiting, with violent pain in the right side, furred tongue, feverishness, inability to lie on either side, yellowness of the conjunctive and skin, anxious expression of the countenance, clay-coloured stools, and very dark urine, symptoms which showed that the attack was dependent on congestion of the liver.

The bowels were kept regularly open by means of purgatives and enemata. Chloride of ammonium was prescribed, and linseed-meal poultices applied to the sides. Vapour-baths were given every night; these caused very free diaphoresis. The patient took milk and other liquid nourishment. The acute symptoms gradually abated, and the patient, although weak for a long time, at length improved so much that there seemed to be every prospect that the liver had once more regained its normal functions. During this attack, there had been well marked hypertrophy of that organ ; but, on recovery, it seemed to be about the natural dimensions.

Taking advantage of his seemingly robust condition, the patient unfortunately, during very cold weather, with easterly winds, exposed himself incautiously to the air, and, in consequence, canght a severe chill. From this I date the commencement of the illness, which culminated in the formation of an abscess. During this attach, I at first did not attend the ratient, as the family had called in a former old medical attendant, who treated the case by applying leeches to the right side, and afterwards continuous poulticing. On consultation with this centleman, we found that the patient was confined to bed, and was in a very emaciated condition. There was the usual very anxious expression of countenance, and free perspiration. The eyes were dull, and the conjunctivæ yellow. The bowels were kept open by laxatives, etc., and there was great general weakness. There was now very little pain ; but, on examining the patient, I found a considerable bulging of the right side, which approached to the front of the chest. On palpation, there was manifest fluctuation of a well defined tumour. I liagnosed the case to be abscess of the liver, and my opinion was that the cavity was of considerable size. We considered the case fully, and, after discussing the propriety of aspiration, we came to the conclusion that it would be advisable to leave the matters to nature's course. The result fully justified our decision. Poulticing with linseed-meal was assiduously continued, and the bowels were kept open by laxatives, and, when necessary, by cnemata. The patient renained in a very weak state, owing to the small quantity of light nourishment which he could swallow. Shortly. afterwards, I was hastily summoned to see the patient, and I found him extremely weak ; he told me that, a fow minntes before sending for me, he felt a sudden feeling of extreme weakness coming over him, "like as if he were going to die," as he expressed it, and he thought that he then felt something trickling into his bowels. I at once looked at the 'swelling, and found that there was evidently a diminution in its size. I advised the poultices to be continued, and 
if the bowels did not act thenselves in the morning, to give an injection.

I was now of opinion that the abscess had burst into the bowels, but inulil not be quite positive of this until I saw what was passed by stuol next morning. The evacuations were ordered to be kept, and, "III inspeting them in the morning, I found them to be liquid, very firtill, and mixed with a greonish fluid. I was now satisfied that the abse'ss had burst into the bowcls; and, on closely examining the welling in the patient's side, it appeared to be considerably limin. ished in circumference and in prominence. There was now, at one yot on the surface, an appearance as if the abscess would noint outside; in a few days, it evacuated itsclf by this means. The discharge that came away was very great, and the smell from it was so horrible that the patient suffered great discomfort. Every menns was adopted to ventilate tho bedroom, and to try to lessen the abominable odour, but to very little purpose, as the discharge continued profuso for several day's. There was evidently a very large cavity, as there was also a grent discharge from the bowels. After the abscess opened into the bowels, the case seemed so critical that I thought it advisable to ask Dr. Macnee, of Inverness, to meet us in consultation. He adrised that nothing of an operative nature was necessary under the circumstances, and recommended measures to support the general strength. Brand's essence of beef was of considerable assistance in restoring the exhausted system, and, under its grateful sustenance,
our patient made rapid improvement.

I am glad to add that the patient continued to make an uninterrupted recovery, and he now apjears to enjoy very good health. The aliseess-e'avity has evidently healed completely. In this case, there was a very large abscess in the liver of a man who
harl never leen subjected to the extreme heat and discomforts of a resilence in a tropical country. The condition has been so often insisted upon as an important factor in the production of large abscess of the liver, that it is extremely puzzling to come across a case of such maunitucle as the one I have just related, when we have no such his. tury to fall bick upon. There was, moreover, no evidence of the liationt having suffered from other exciting causes of hepatic abscess, such as intemperance, ulcerated bowels, dysentery, chronic diarrhoea, or absorption of purulent matter. There was little or no material henefit evidently derived from the treatment of chloride of ammoninm and other measures for the prevention of the development of suppuration, as the liver seemed as prone as ever to suffer from external influences. Of course, the patient may be said to have foolishly exposed himself, and, perhaps, he may have been more susceptible to the influence of chilly winds, but a healthy liver would probably have sustained no such damage. It is remarkable how, in this case, Nature managed to bring matters to a safo termination. In a most valuable and interesting article by Sir Joseph Fayror, on "Tropical LiverIbscess," which appeared in the British Medical. Jounnal, June $1 \mathrm{th}, 1884$, the author advises very strongly that, as soon as an abscess forms in the liver, it should be opened, and even goes so far as to indicate that there is positive danger in delaying operation. With all lue deference to the distinguished author, the case I have given above shows that there is a necessity for using some caution in advocating operative interference in every case where pus is suspected to be present. I shall, in future, if called upon to trent such a case, place oreater reliance on the "vis medicatrix naturæ."

I fully agree with Sir Joseph Fayrer when he states that, " in any tain," but can hardly endorse serious affair, and the result is uncertain," but can hardly endorse the remark, "never allow a liverabscess to point and cause gangrene of the abdominal wall from preswhere a simple incisint inevitable death by exhaustion, in such cases where a simple incision wonld, in all probability, have relieved suffering, and might have saved life." The case I have just described rather disproves this latter advice, as the pressure did not appear to have the tendency to promote such an alarming state of matters.

In conclusion, I think it may be fairly assumed that the prime factor in the production of the abscess in this present case was all attack of hepatitis, brought on through the exposure to cold.

Ar the Brussols University, no less than 157 British physicians and surgeons have obtained the degree of M.D. since $1864 ; 29$ passed last
year, and 20 were unsuccessful.

Presentation. - At a recent meeting of the Committee of the Oucen's Hospitul, Birmingham Mr. John Clay was formally presented, institution wis professional colleagues and the lay executive of the institution, with a beautifully illuminated and framed address, recapitulating his long and valuable services to the charity, upon his refirement fruin the prost of Obstretric Surgeon, and his accession to it l.lace anongst t?e couscil:ing officers of the lospital.

\section{THERAPEUTIC MEMORANDA.}

\author{
COCAINK.
}

Arriki a trial of cocainc-liydrochlorate as a local anusthetic, I am able to add my testimony of its very great value. I have been using a 20 per cent. solution, but a much wcaker one will, no donbt, answer very well in ophthalnic practice. In laryngoscopic examinations it is gimply invaluable. After the uvula and fances liave been painted with the solution, the practitioner will find no difficulty in obtaining a good view of the opening of the glottis. With its assistance, I have just been able to make a prolonged laryngoscrpic search for a pin which a patient had swallowed, and which he could feel sticking in his throat. The introduction of the mirror did not inconvenience him at all, and I was able at once to proceed to a complete exploration of
the region.

Two applications of the solution, in a severe case of double tonsillitis, afforded immediate relief from all liscomfort, and the patient, a girl aged 14, was for some hours afterwards able to swallow without pain, though the inflammation and swelling remained the same. I have applied the solution with complete success in a case of painful fissure of the anus. The great hindrance to the free use of cocaine is its price, which, I am informed, at present ranges from eighteenpence to half-a-crown a grain. I am aware of no reason why the name of the plant should be srelt
otherwise than coca.

F. St. Gforge Mivart, F.R.C.S.El., 65, Green Street, W.

\section{THE TREATMENT OF TUBERCLLOSIS.}

Dr. K. Shisciletox Surti's almission that, in many of his cases (of tuberculosis), no diminution in the number of bacilli, and sometimes no improvement in the condition of the patients, followed the use of iodoform, renders it somewhat unnecessary on my part to adduce any evidence in favour of the point for which I contend-that iodoform, in therapcutic doses, is inert upon the bacillus of tubercle. The cases rccorded in Dr. Snith's communications are admitedly selected ones; and I venture to think that, in order to a corret: judgment, not only should these be subnitted, but also those in which the drug proved inefficacious. I therefore look forward with a considerable degree of interest to the publication in full of Dr. Smith's paper in the forthcoming Transactions of the International Congress. Meanwhile, I must repeat that my experience in the use of indoform has been dis. appointing; and, as a result of a fair trial, I cannot say that I have been able to satisfy myself that iodoform has any influence upon the tubercle-bacilli. The following cases are illustrative of my results.

('ASE I. - A male patient, aged 59, was in the first stage of tubercular laryngitis and commencing consolidation of the right pu!monary apex. Tubercle-bacilli were present in fair quantitics in the expectoration and laryngeal secretion. On Norcmbrr 20th, 1s83, he commenced insufflations of iodoform (grs. $1 ! 11$, 4 ) and morphia (gr. 1). On December 20th, the bacilli were rather nore numerous. On January 16th, 1854, he was using fifteen nnains of iodoform daily by insuftlation, and since December 24th had been applying to the larynx an ointment of iodoform (iodoform $3 \mathbf{i}$, simple ointment s̃i) night and morning. The bacilli were now almost twice as numerous as before commencing the use of iodoform; the throat was much easicr. The patient a few days afterwards gradually became excited, with delusions of mistaken identity, and was seen by Dr. Batty Tuke, who agreed with me in attributing this to the use of the iodoform, which was accordingly discontinued, with cessa. tion of the mental symptoms. Subsequent examinations of the sputum showed the bacilli about as numerous as cluring the treatment by iodoform.

CAsE II.-A male, aged 30, was seen on February sth, 188t. He complained of cough of six months' duration. He was formerly quite well. There was dulness on the left side over the first and second ribs, with crepitation and increased rocal resonance. The morning sputum was muco-purulent, with about one hundred bacilli, more or less, in the lield of the microscope. I ordered a pill composed of a grain of iodoform, with one-sixth of a grain of sulphide of calvium, three times daily; and inunction of iodoform-ointment (as in the preceding case) night and morning. On March 7 th, the patient reported himself as feeling better and stronger. The sputum was scanty, purulent; about two hundred bacilli, at least, were seen in the field. April 9 th. He still continued the treatment. The sputum was muco-purulent. Bacilli were present in great numbers, so that the could not be counted. He had more cough and dyspncea, with slight diarrhoea. Treatment by ioloforin was discontimued so.n afterwiluls, as the patient became rapidly worse. 